\title{
Bound to hospitality
}

An asymmetry of power in the Finnish church asylum movement

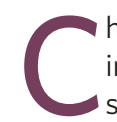

hurch asylum, a practice aimed at assisting migrants with precarious residence statuses, has been enacted in Finland particularly since the 2010s. As a result of migrants' insecure residency, their capacities of action are often restricted. They have been deprived of access to health and social services and schooling, and their movements limited due to fear of the police and deportation. This article analyses the autonomy and capacities of action of those in church asylum and the congregations assisting them, following Albert Bandura's classification of individual, proxy and collective agency. The data consists of interviews ( $\mathrm{N}=25)$ with employees of congregations and people who have been in church asylum. According to the results, the agency of people in church asylum was often drastically limited, which led to a need for proxy and collective agencies. Immigration regulation created a structure controlling the autonomy and capacities of both migrants and congregations. All modes of agency were inventively applied.

\section{Introduction}

As a reaction to the so-called immigration crisis in Europe and North America the ancient tradition of sanctuary has been revived in many Western societies in recent decades. The idea of sanctuary is known in several religious traditions, including Judaism, Islam and Christianity (Marfleet 2011; 'Abd al-Rahim 2008; Rabben 2016). Different forms of sanctuary practices have been evoked not only inside religious communities, but also in secular institutions, such as universities and municipalities. The contemporary church asylum movements are, however, almost exclusively connected to international migration. Church asylum is used for helping people who fall between gaps inside the system of international protection. Usually church asylum takes place when an asylum seeker receives a negative asylum decision and faces a threat of deportation. Churches can intervene if they suspect there have been errors and/or deficiencies during the asylum process, or if the deportation would damage or break up the asylum seeker's family.

This article aims to disentangle how parish workers who have been involved in a church asylum situation have experienced the power dynamics present in a relationship of hospitality between the host and the guest. Hospitality is a central value in the Christian thought (see Bretherton 2006: 128-46), and it has been highlighted among Christian churches as a response to the socalled migration crisis. As Marguerite La Caze (2013) points out, hospitality is an act or a set of acts, rather than made up of certain attitudes or passions. However, hospitality in the lives of Christian communities derives from an ethical code of welcoming a stranger and helping those in need. While hospitality is a major narrative 
in church asylum practice, it also entails asymmetrical relations between the parish providing church asylum and the protegee.

As a background to church asylum, I will present a general outline of the contemporary church asylum movement in Finland in the following section. After that I will move forward to the scope of this study and its methods and data. In the main section I will focus on church asylum as an act of hospitality involving dependency of the guest within the church asylum, and how parish workers act as proxies for protegees with limited autonomy in relation to the hospitality. In the final section I will bring these viewpoints together and discuss them briefly in the context of migration policies.

\section{A history of church asylum in Finland}

Contemporary church asylum movements have occurred in different parts of the Western world since the 1980s. The most well-known and widely documented examples are the New Sanctuary Movement in the US and Canada (Tomsho 1987; Lippert 2005; Coutin 1993; Cunningham 1995) and the German church asylum movement, Asyl in der Kirche (Just 2012; Mittermaier 2009; Ökumenische Bundesgemeinschaft Asyl in der Kirche 2004). Church asylum practice has been utilized also in the Nordic countries (Pyykkönen 2009; Loga et al. 2013), in France (Patsias and Williams 2013) and in the UK (Rabben 2016).

In Finland, the first church asylum cases $^{1}$ emerged in Swedish-speaking congregations in the early 1990s. They were

1 Several scholars of church asylum have criticized and avoided the term 'case' (see Oda 2013: 148; Lippert 2005: 89-90); while acknowledging their concern, I here use the term for the purposes of clarity and consistency. connected to international church asylum movements, which had been initiated in particular in Germany and other Nordic countries in the 80s. In 2007, the Finnish Ecumenical Council published the first church asylum guidelines (Kirkko turvapaikkana, 'Church as a refuge'), which was shortly after followed by a high-profile church asylum case (Loga et al. 2013: 124-6). This was the case of Naze Aghai. She had fled her country of origin, Iran, and was afraid of torture and persecution if she were to be deported back. She had also escaped a forced marriage, but had nevertheless received a negative asylum decision from the Finnish immigration service. The case made church asylum practice visible to a wider public, and Naze Aghai gave voice not only to her own case but also that of other asylum seekers, who faced tragic and inhumane situations. After Naze Aghai was granted a permanent residence permit in Finland, the local vicar, Jouni Lehikoinen, commented to the press that the decision was not meaningful only to the congregation and Aghai herself, but also to the future of church asylum practice. It was proven to function and even to have a certain societal need. And it certainly did - as became increasingly evident in 2015 .

The church asylum practice started to acquire a more institutionalized form after the case of Naze Aghai and the first church asylum guidelines were published (Ahonen 2018a). Both the guidelines published by the Finnish Ecumenical Council in 2007 and the church asylum instructions published by the Evangelical Lutheran Church of Finland (2011/15) address the main principles in church asylum cases. Firstly, the initiative must come from the asylum seeker, and the church does not advertise the practice. The second principle is openness; meaning that the congregation does not hide the person, but announces to the 
local police that they have taken the person under their wings. The aim is to change the situation so that the person in church asylum could eventually reside in the country legally. In addition, in principle church asylum is an ad hoc type of intervention and it should be used only as a final resort if other means of helping the person or family have proven insufficient. Church asylum is a temporary practice, lasting usually from few months to, in some cases, several years. In the best-case scenarios, churches can provide help - in the form of legal assistance for example - even before church asylum is actually needed. Thus, churches can, somewhat paradoxically, also take actions that prevent the need for church asylum.

Most commonly church asylum is applied when an asylum seeker has received a negative asylum decision but there is a good reason to believe that deportation would violate their fundamental rights. This is the case especially in post-2015 church asylum situations in Finland. In 2015 and 2016 the Finnish government passed several amendments that weakened asylum seekers' protection under the law (see Lyytinen 2019). Restrictions on asylum policy resulted in a rapid decrease in the asylum recognition rates, from 57 per cent to 34 per cent ( 2015 vs. 2016). Furthermore, due to changes to the Aliens' Act, officials no longer granted residence permits on the basis of humanitarian protection. The basis was used in cases where the applicants' country of origin did not meet the requirements for what was known as secondary protection and it was not safe for applicants to return to their countries of origin. The amendment increased the number of undocumented migrants (Ahonen and Kallius 2019). Instead of relieving the situation of the undocumented, the Finnish Ministry of the Interior labelled them as illegal and pushed, for example, municipal services and third sector actors to report anyone who didn't have a residence permit. In 2016 the Ministry of Justice also tightened rules on asylum decision appeals. Additionally, asylum seekers were no longer allowed to automatically have their legal aid attorneys present at hearings to determine the case for receiving protection. The numbers of officials responsible for processing asylum applications at the Finnish immigration service reported anonymously in the media that they felt they were under pressure to make quick decisions and reject an increasing number of applications.

These amendments and political resolutions show how asylum seekers have not been guaranteed to receive a just asylum process. As the so-called migration crisis soon became the most contested topic in Europe, it also created political turmoil and controversy. ${ }^{2}$ In 2015 the Finnish state and the municipalities were mostly illprepared for the sudden influx of asylum seekers. NGOs and congregations of different denominations were often the first ones to provide assistance and immediate aid for the incoming migrants (Siirto and Niemi 2019). The Home Accommodation network, which provided asylum seekers accommodation in private homes, was at first initiated among religious actors, even though it shortly after also gathered secular actors (Merikoski 2019). After the asylum seekers who had arrived in 2015 began to receive negative asylum decisions, it was only natural to seek help from the same places as before: churches. Finnish churches have adopted several means of aiding migrants and asylum seekers. They have given statements to support those in flight, taken part in demonstrations, and

2 For comparison of Nordic countries see Franko et al. 2019. 
offered help at the grassroots level.

In their church asylum guidelines, both the Evangelical Lutheran Church of Finland and the Finnish Ecumenical Council emphasize the importance of autonomy for those in church asylum. However, the opportunities for full self-determination are in practice limited as a result of the undocumented residence of those protected by the church. Lack of documentation usually results, for example, in exclusion from welfare services, high dependence on relatives and friends, and risks of exploitation on the labour black market (Könönen 2015). Members of the undocumented population may also be afraid of getting caught by the police; thus, public spaces contain borders that are as a rule invisible to, and non-existent for, the native population (see Hynes 2011).

\section{Methods and data}

Undocumented migration and associated phenomena, including church asylum movements, impose certain methodological limitations. As Vicky Squire (2012) and Grace Yukich (2013) have pointed out, church asylum is a 'messy' research topic, which does not fall into a single register and cannot therefore be reduced to a simple definition. This study falls into the category of empirical qualitative research, thematic half-structured interviews being the main method. This article is a follow-up study of my doctoral dissertation on the Finnish church asylum movement (Ahonen 2019a).

The primary data consists of interviews $(\mathrm{N}=25)$ with employees of congregations. The interviews were conducted in Finnish. ${ }^{3}$ Affiliated denominations in church asylum cases were Lutheran, Orthodox, Catholic,

3 For more detailed description on the data collection, please see Ahonen 2019a: 31-4, 36-40.
Baptist and Pentecostal. In most of the cases congregations of different denominations co-operated in arranging and providing church asylum. However, the church asylum situations were not only ecumenical, but also inter-religious: usually those who had been in church asylum were of a Muslim background. On the other hand, the Christian conviction of some of the people who had been in church asylum was the reason why they had felt discriminated against in a reception centre and why they had eventually sought protection from the church. Hence religion played a significant role in church asylum situations.

Nearly 70 per cent of the Finnish population are members of the Evangelical Lutheran Church of Finland, and Lutheran thought is well embedded in Finnish society and its welfare state. The Lutheran church plays a varied role amidst the public sector and civil society (Pessi and Grönlund 2012), and the church has a wider societal role beyond its religious one. Together with the Orthodox Church of Finland the Lutheran church has a special status within the state, allowing it to collect taxes. However, the Orthodox population forms only a small minority, Orthodox devotees consisting from one to two per cent of the population. Other denominations form small yet active minorities.

Because the interviews relate to people who had been residing in Finland as undocumented migrants the topic was highly sensitive (see Lahman et al. 2011; Clark-Kazak 2017). This had to be acknowledged before, during, and after the study. Before the data collection the research plan was evaluated by the research ethics committee of the University of Eastern Finland in 2015. Research on sensitive topics, as the one at hand, has significant implications not only for protection of the data and anonymity, but for the data 
collection itself. In most of the cases it was the parish that brought me into contact with those who had been protected by the church. While interviewing the people who had been in church asylum, I sometimes understood that the interviewees had given their consent because of the indebtedness they experienced towards the parish workers. This intangible debt they were 'paying back' by talking to me. My personal interpretation was also reflected in some of the interviews, both in case of the church asylum providers and those protected by the church.

\section{Church asylum, hospitality, and agency \\ Church asylum as an act of hospitality}

Hospitality is an intrinsic and central value in Christian thought. As a response to the asylum seekers and refugees, Christian churches have stressed the importance of hospitality. However, hospitality cannot be viewed as a single, uniform rationale; instead, it is always interpreted and produced within a certain tradition. Jacques Derrida differentiates between pure and conditional hospitality. Conditional hospitality '... is the way hospitality is usually understood in many cultures ... The host remains the master in the house, the country, the nation, he controls the threshold, he controls the borders, and when he welcomes the guest he wants to keep the mastery' (Derrida 1999: 69). On contrary, pure or unconditional hospitality '... implies that you don't ask the other, the newcomer, the guest, to give anything back, or even to identify himself or herself. Even if the other deprives you of your mastery or your home, you have to accept this' (Kearney and Dooley 1999: 69-70). According to Derrida, the concept of an invitation makes the distinction between conditional and unconditional (pure) hospitality. Unconditional hospitality entails an elem- ent of surprise, while conditional hospitality includes preparation and expectation (La Caze 2013: 120). In this regard church asylum can be seen as an unconditional form of hospitality; because it is used as an ad hoc intervention, it does not include any preparation. Within the Christian tradition hospitality is understood in its unconditional form, as Luke Bretherton (2006: 149) describes it: 'To warrant hospitality the stranger neither has to be deserving in some way, nor do they have to earn the right to it, nor must they possess some innate capacity that renders them worthy of acceptance among the human community, nor is welcome dependent on a well meaning humanitarian impulse on the part of the giver.'

According to Christine Pohl (2006), hospitality is of a voluntary nature. It arises from free choice - and if not, it does not quite fit the definition of unconditional hospitality. How, then, does the practice of church asylum meet the characteristics of unconditional hospitality? A defining starting point to the question is that church asylum is an institutionalized form of hospitality. Employees of the parishes said they acted in church asylum as part of their working role, following the ethics of hospitality dominant in Christian thought. Even if they personally were engaged in the ethics of hospitality, the decision of granting church asylum was mounted on the basis of the values of the institution. Some of the interviewed parish workers recalled that church asylum had blurred the boundary between their working life and private life. They had used their free time to visit those in church asylum and were immensely emotionally engaged with those in church asylum. One of the interviewees said: 
Emotionally it really got under my skin, I got so attached to the children and the adults.... When the family was to be deported, despite of all this, and they clung to me as their last resort, it was rough. ... We [employees of the parish] wondered what the meaning of all this is, for the family, to prolong this process, they wished so hard that we could change their [negative asylum] decision. They had unrealistic expectations. ... It was a huge load of emotions that they gave to us.

The interviewed parish worker had experienced the emotional load resulting from the act of hospitality, church asylum, as excessive. They expressed a sense of compassion and obligation (cf. Oda 2013: 1545). Even if the act of hospitality was of a voluntary nature in the beginning, it became a burden, even an unwanted one, as it proceeded. The situation they described also reflects the 'emotional economy' present in a particular church asylum situation. An asymmetrical relationship between a host and a guest leads to a situation in which the one receiving a 'gift' of hospitality is indebted with gratefulness (Ahn 2010). One of the interviewed parish workers recalled how their Christian community perceived the people in church asylum in various ways. The people protected by the church were Muslims, and they were celebrating Ramadan while in church asylum, and therefore did not eat or drink during the day. Some of the employees working at the parish experienced them as 'ungrateful' as they followed their own eating habits. The example shows how unconscious economic balance lies beyond the idea of hospitality, that is, a situation of invisible debt. The guest presented a fracture in the normative order maintained by the host.

Hospitality in its conditional form raises a question as to who is deserving enough to receive it. A certain characteristic of a person in need makes them more prone to be seen as a victim - and sometimes even as a non-acting subject. In the most famous Finnish church asylum cases, which had wide and long-term media coverage, the persons protected by the church were women (Ahonen 2019a: 50; Ahonen 2019b: 14). In the media they were often depicted as vulnerable and subject to unjust authorities in their countries of origin. Regardless of whether that portrayal was authentic and conscious, it served as a means to legitimize church asylum to the public. Therefore, gender was rhetorically used to enlarge the capacities of action. As within the official system of international protection, church asylum practice may presuppose certain 'legitimate narratives' of need for protection (Farrier 2011).

The dependency of the guest in church asylum Conditional and unconditional forms of hospitality differ not only in their invisible economic relations, but also in terms of agencies, both on the side of the guest and the host. Agency has been defined as the capacity to act and make choices (Barnes 2000; Elder-Vass 2010). According to Albert Bandura (2001), agency can be classified into three forms: individual, proxy and collective agency. Individual agency refers to modes of actions that people can personally and individually engage in, whilst proxy agency is a socially mediated form of agency. In proxy agency people (who personally lack capabilities or resources for one reason or another) seek other people with necessary expertise and resources to act on their behalf. Collective agency is a mode of action in which several individuals or actors come together with their respective resources, thus creating a nexus of multiple capabilities. 
Losing control over one's life is often the most distressing thing for migrants who are in church asylum. Their and their family's future depends on the immigration services' decision, and in their daily lives they are dependent on the congregation who has granted them church asylum. In church asylum this disparity in terms of power and possibilities of action often becomes evident. Those in church asylum do not usually have a residence permit in Finland, they have no income and their access to public services is either very limited or completely restricted. In one of the church asylum cases interviewed for this study the people in the church asylum were so afraid of the police that they didn't even go outside of their home; the congregation took care of their grocery shopping and other daily errands (see Ahonen 2018b: 14-18). Even though people in church asylum were grateful to those who had helped and assisted them they were, however, dependent on the hospitality of the congregation. Hospitality, therefore, entails an intrinsic and sensitive power balance. It is crucial to point out the shortcomings of the relationship between a host and a guest, that is to say, the relationship is unequal and asymmetrical in terms of power. The guest is subject to the authority and goodwill of the host. However, these positions can also be challenged and negotiated (Bendixsen and Wyller 2019: 8).

While on a practical level people in church asylum are often highly dependent on the congregation who gives them protection, their daily lives are dependent on the decisions the migration authorities make. An embedded suspicion towards the asylum seeker's reliability and authenticity prevails in the asylum system. One of the interviewed asylum seekers, who contributed to the larger research project, talked about the immigration mentality, as he put it: 'he [the asylum officer] was investigating me, treated me like a criminal or an animal. They believe the fake story and the simple story, but they don't believe the real story.' When the interviewee drank water during the interview, the asylum officer had pointed this out saying: 'aren't you a Muslim, it's Ramadan' This immigration mentality, as the interviewee called it, is based on suspicion and a quest for any minor inconsistencies in the asylum seeker's story, and it is also inclined to cause occasional errors in asylum decisions, to the asylum seeker's disadvantage. The culture of suspicion was reflected in the experiences of those in church asylum and their capabilities of action, as they constantly had to vindicate their existence and self-narrative. While the congregation sought to show the person hospitality, the state apparatus run by the immigration service seemed to reflect, on the contrary, inhospitality or even hostility (see Farrier 2011: 153-80; Franko et al. 2019).

\section{Taking action as a proxy}

The relation between a host and guest with an unclear status within the state regularly led to a situation in which the host - the parish - had to act as a proxy. Strong disparity in terms of power and agency was difficult and distressing not only for those in church asylum, but also for the employees of the congregation which was protecting them. One of the priests I interviewed reflected:

Interviewee: It was one of those tragicomic decisions. I had to decide over the schooling [of the child of a family in a church asylum]. When he went to school the school knew that he's registered with a false name. I was designated as his caretaker, and another employer of ours was designated the 
other caretaker. And then I've done some life-saving decisions in a very short time, so it's quite extraordinary position I have ended up in.

Interviewer: That sounds quite demanding, I guess it's not every day that priests are requested to make lifesaving decisions.

Interviewee: Well yes, I've done such decisions over my own children before. Now I had to decide on behalf of another family's children.

The interviewed parish worker described the church asylum situation in which he had to take responsibility for the children of the family that was protected by the church. Because the family members were residing in the country undocumented, that is to say without a residence permit, the parents could not organize the schooling of the children themselves. According to the Finnish constitution, every child residing in Finland has a right to go to school. However, it is unclear whether this right is always implemented. The parents could not contact the school themselves, not only because they were unaware of the Finnish system and their rights, but also because of the language barrier. They were also afraid of what would happen if the school staff informed the local police about their situation. For these reasons, the local congregation had to act as a mediator; there was no room for the individual agency of those in church asylum, and that created the need for proxy agency. The described situation also highlights the agency-structure dilemma in the church asylum cases: the immigration policies (the structure) manifest themselves in the lives of those people who fall between the categories of legal residence. The individual's agency is bounded by the immigration policies and its restrictions.

The agency of the parish was nevertheless limited - such that those limits were porous and adjustable. While congregations were in a position of taking sometimes extreme responsibilities over those in church asylum, their status and capacities varied in different settings. In one of the interviews employees of a congregation recalled:

Interviewee 1 (deacon): Even though we also have higher degrees in social and health care, they [staff of the reception centre] often call me a volunteer.

Interviewee 2 (vicar): And we who do not have professional expertise in health care, we have no professional expertise at all. Representatives of the same profession, if they work for the congregation, they have no professional skills. Even if they have the same education, often even higher education [than those employed at the reception centre], they are nothing.

Even though the congregation visited and aided the reception centre as a part of their work and diaconia, they were referred to as 'volunteers' by the staff of the reception centre. They pointed out that they had the same level, or higher, of education as those working at the reception centre, but even the vicar of the congregation was labelled as a volunteer and non-professional, in spite of her status and master's degree in theology. Consequently, the personnel of the parish were excluded from interprofessional collaboration, which implies that the professionality and specific capabilities of the employees of the congregation were being ignored or even scorned. 
This led to a situation in which the congregation was deprived of collective agency. On the other hand, in other situations the congregation had managed to form a hub that brought together asylum seekers and other migrants as well as NGOs and FBOs (faith-based organizations). Therefore, the congregations were sometimes creators and initiators of collective agency.

These examples show that church asylum is, as a form of hospitality, an extreme case. People in church asylum are highly dependent on the congregation, which in turn must take a lot of responsibility for them. This situation may also create challenges when it comes to how, for example, cultural, religious and gender differences are acknowledged within the terms of hospitality. Disparity in terms of power and agency poses a question as to how otherness is recognized and enabled. As mentioned before, often people who have been in church asylum in Finland have been Muslims. In these cases, church asylum creates an inter-religious space, where religious traditions encounter each other and overlap (Ahonen 2019a: 50-2). That being said, this inter-religious space is not fundamentally free from normative hierarchies. Even though church asylum, like other forms of diaconal help, is in principle gratis, there is a risk that a person in church asylum feels pressure, for example, to convert to Christianity. Conversion can also create a threat of religious persecution. These risks can be avoided only if they are explicitly expressed. This was generally acknowledged among employees of congregations:

Interviewee: If the people in their home countries find out, for example that they have converted to Christianity, their relatives back there can be revenged for that. So it's very complex.
Interviewer: When you baptized them did you worry that it might have such consequences?

Interviewee: We made it clear to them that if they decided to get baptized, it could have consequences. They understood it, and still wanted to do it.

In these situations, the congregation had to take moral responsibility over actions of the newly converted and their well-being. The inter-religious dimension of their work therefore brought with it certain challenges and uncertainties. However, not all the interviewees viewed conversions as potentially harmful:
Interviewee: If they convert and get baptized they can, as Christians, become missionaries among their own culture, let alone some of them might return to their home country as missionaries.

In this story the power relations present in church asylum as hospitality become evident, even in a way that conflicts with the idea of Christian hospitality (Bretherton 2006: 121-59). In diaconia, including work among asylum seekers and those in church asylum, a strong emphasis on missionary work could potentially lead to situations in which the security of those involved with Christian communities was compromised. These single situations reveal that sometimes congregations endeavoured to make the new converts proxies of the missionary agenda. Overall, the congregation workers were, however, mostly mindful about the risks that the conversion of those in church asylum might entail. 


\section{Conclusion}

Church asylum is a practice that has been used to prevent unjust and possibly illegal deportations of those who have, for example, received negative asylum decisions. In church asylum a congregation or other Christian community provides them with accommodation, legal guidance and takes care of their daily needs. Modern church asylum movements were first initiated in Germany and the United States in the 1980s. Since then the practice has been adopted in different parts of the Western world, and it has been applied also in different secular communities, such as municipalities and universities. The first church asylum cases in Finland took place in Swedish-speaking parishes in the early 1990s, and the practice has since been utilized to assist asylum seekers who may not have received a just asylum procedure.

This article has analysed how parish workers who had been involved in church asylum situations experienced intersections of hospitality and agency. Limited autonomy and capacities of action characterized not only major decisions of the people in church asylum, but also their everyday lives - and hence also the lives of those assisting them. The immigration regime created a frame that regulated not only the migrants' residency, but also cast uncertainties on the entirety of their lives. These uncertainties were then projected further onto parish workers. The limited individual agency of those in church asylum created a need for proxy agency. Congregations took responsibility and care over issues that were beyond the boundaries of their agency. Nevertheless, both the individual and proxy agency of the congregations was also limited. Together with NGOs and other actors they created forms of collective agency, in order to assist those protected by the church.
Hospitality is deeply rooted in the Christian narrative and self-understanding. Church asylum, as an institutionalized form of hospitality, was experienced by the parish workers somewhat as a mix of duty drawing from that narrative and a genuine wish to assist those migrants who faced desperate situations. To fully understand this specific setting where hospitality takes place, we must understand and acknowledge the circumstances preceding church asylum. Most of the asylum seekers who sought church asylum had faced a dead-end: church asylum was their last resort to avoid deportation. Parish workers acknowledged their despair and wanted to help, but also felt a responsibility to respond to their needs. Therefore, the act of hospitality, both on the side of the host and the guest, was not always utterly voluntary (cf. Lippert 2005: 73). Even if the act of hospitality was of voluntary nature in the first place, several parish workers revealed that they eventually felt somewhat trapped in the situation, being unable to put an end to their hospitality.

At least theoretically, church asylum can be described as a form of 'radical hospitality'. As Ilsup Ahn defines, in radical hospitality '...there should be elements of "excessiveness" or "madness" that transcend ordinary moral criteria such as reciprocity or equality' (Ahn 2010: 25). In some cases, commitment to church asylum required the congregation to resist the authorities and question whether decisions made by the Finnish Immigration Service had been legitimate and fair. However, many congregation employees interviewed during this research reported that the decision as to whether to help a person in need was never a real question. They saw hospitality is a crucial value in Christianity, and the gospel explicit in its demand for diaconia. This was regarded as a guiding principle, 
regardless of in what kind of situation the person in need was.

When addressing the question of agency the question of structure also needs to be reflected on (see Callinicos 2004). Undocumented migration is not a selfgenerating phenomenon; on the contrary, it is produced in societal structures (De Genova 2002; Ahonen and Kallius 2019). As a result, the church asylum cases are also generated in national and international migration policies (Ahonen 2019a). The structure, that is to say, the externality of the legal categories of residence in a country, has certain ramifications on agencies of different agents. The agencies of different actors of the church asylum situation are bounded by migration policies, thus they are connected to the border and migration controls and wider national and EU-level migration policies, which can be viewed as generators of church asylum cases. In this sense the social structures are given the primary, imperative role, that to some extent (but not completely and absolutely) determines the limits of agency and the courses of action. Acts of hospitality in situations such as church asylum are hence bound to these structures. This amplifies the understanding of other practices of hospitality in the context of migration in Nordic counties: acts of hospitality can be generous and exclusionary at the same time (Bendixsen and Wyller 2019).

\section{PhD Talvikki Ahonen works} as a postdoctoral researcher at the University of Eastern Finland's School of Theology. Her current research focuses on the assessment of religious conversion and conviction within the system of international protection.

\section{References}

'Abd al-Rahim, Muddathir. 2008. 'Asylum: a moral and legal right in Islam', Refugee Survey Quarterly, 27(2): 15-23.

Ahn, Ilsup. 2010. "Economy of "invisible debt" and ethics of "radical hospitality": toward a paradigm change of hospitality from "gift" to "forgiveness", Journal of Religious Ethics, 38(2): $243-67$

Ahonen, Talvikki, 2018a. 'Kirkkoturvainstituution muotoutuminen Suomessa', Uskonnontutkija, (7) 1: 1-23.

- - 2018b. 'Seurakunnat kielteisen turvapaikkapäätöksen saaneiden tukena: kirkkoturvatoiminnassa sovelletut strategiat', Diakonian tutkimus, 1: 6-27.

- 2019a. 'Nykyaikainen kirkkoturvatoiminta Suomessa, PhD dissertation, University of Eastern Finland.

- - 2019b. 'Valtio valtiossa ja virkamiehet saarnastuolissa. Kirkkoturva julkisessa keskustelussa vuosina 2007-2010 ja 20152018', Politiikka, (61)2: 103-26.

Ahonen, Talvikki, and Annastiina Kallius. 2019. 'Paperittomuuden tuotanto ja hallinta Suomessa vuosina 2015-2017', in Turvapaikanhaku ja pakolaisuus Suomessa, ed. Eveliina Lyytinen (Turku: Siirtolaisuusinstituutti), 89-102.

Bandura, Albert. 2001. 'Social cognitive theory: an agentic perspective', Annual Review of Psychology, 52: 1-26.

Barnes, Barry. 2000. Understanding Agency: Social Theory and Responsible Action (Thousand Oaks, CA: Sage).

Bendixsen, Synnøve, and Trygve Wyller. 2019. Contested Hospitalities in a Time of Migration: Religious and Secular Counterspaces in the Nordic Region (London: Routledge).

Bretherton, Luke. 2006. Hospitality as Holiness: Christian Witness Amid Moral Diversity (Farnham: Ashgate).

Callinicos, Alex. 2004. Making History: Agency, Structure, and Change in Social Theory (Leiden: Brill).

Clark-Kazak, Christina. 2017. 'Ethical considerations: research with people in situations of forced migration', Refuge 33(2): 11-17.

Coutin, Susan Bibler. 1993. The Culture of Protest: Religious Activism and the US Sanctuary Movement (Berkeley: Westview Press).

Cunningham, Hilary. 1995. God and Caesar at 
Rio Grande: Sanctuary and Politics of Religion (Minneapolis: University of Minnesota Press).

De Genova, Nicholas. 2002. "Migrant “illegality” and deportability in everyday life', Annual Review of Anthropology, 31: 419-47.

Derrida, Jacques. 1999. 'Hospitality, justice and responsibility: a dialogue with Jacques Derrida, in Questioning Ethics: Contemporary Debates in Continental Philosophy, eds. Richard Kearney and Mark Dooley (London: Routledge), 65-83.

Elder-Vass, Dave. 2010. The Causal Power of Social Structures: Emergence, Structure and Agency (Cambridge University Press).

Evangelical Lutheran Church of Finland. 2011/ 15. Kirkkoturvakäytäntö seurakunnissa, available at $<\mathrm{http} / /$ sakasti.evl.fi/sakasti.nsf/ o/21297824E22C9061C22577580028EA55 /\$FILE/Kirkkoturvak\%E4yt\%E4nt\%F6\%20 seurakunnissa\%202015.pdf> (accessed 9.10.2020).

Farrier, David. 2011. Postcolonial Asylum: Seeking Sanctuary Before the Law (Liverpool University Press).

Finnish Ecumenical Council. 2007. Kirkko turvapaikkana, Suomen Ekumeenisen Neuvoston julkaisuja, 82, <http://www. ekumenia.fi/data/liitteet/kirkko_turvapaikkana_2007-2.pdf> (accessed 9.10.2020).

Franko, Katja, Maartje van der Woude, and Vanessa Barker. 2019. 'Beacons of tolerance dimmed? Migration, criminalization, and inhospitality in welfare states', in Contested Hospitalities in a Time of Migration: Religious and Secular Counterspaces in the Nordic Region, eds. Synnøve Bendixsen and Trygve Wyller (London: Routledge), 55-75.

Hynes, Patricia. 2011. The Dispersal and Social Exclusion of Asylum Seekers: Between Liminality and Belonging (Bristol: Policy Press).

Just, Wolf-Dieter. 2012. 'The rise and features of church asylum in Germany', in Sanctuary Practices in International Perspectives, eds. Randy Lippert and Sean Rehaag (London: Routledge), 135-47.

Kearney, Richard, and Mark Dooley. 1999. Questioning Ethics: Contemporary Debates in Continental Philosophy (London: Routledge).

Könönen, Jukka. 2015. 'Tilapäinen elämä, joustava työ. Rajat maahanmuuton ja työvoiman prekarisaation mekanismina, $\mathrm{PhD}$ dissertation, University of Eastern Finland.

La Caze, Marguerite. 2013. Wonder and Generosity: Their Role in Ethics and Politics (Albany: State University of New York Press).

Lahman, M. K. E., B. M. Mendoza, K. L. Rodriguez, and J. L. Schwartz. 2011. 'Undocumented research participants: ethics and protection in a time of fear, Hispanic Journal of Behavioral Sciences, 33(3): 304-22.

Lippert, Randy. 2005. Sanctuary, Sovereignty, Sacrifice: Canadian Sanctuary Incidents, Power and Law (Vancouver: UBC Press).

Loga, Jill, Miikka Pyykkönen, and Hanne Stenvaag. 2013. 'Holy territories and hospitality: Nordic exceptionality and national differences in sanctuary incidents', in Sanctuary Practices in International Perspectives, eds. Randy Lippert and Sean Rehaag (London: Routledge), 121-34.

Lyytinen, Eveliina. 2019. Turvapaikanhaku ja pakolaisuus Suomessa (Turku: Siirtolaisuusinstituutti).

Marfleet, Paul. 2011. 'Understanding "sanctuary": faith and traditions of asylum', Journal of Refugee Studies, 24(3): 440-55.

Merikoski, Paula. 2019. 'Hospitality, reciprocity, and power relations in the home accommodation of asylum seekers in Finland', in Contested Hospitalities in a Time of Migration: Religious and Secular Counterspaces in the Nordic Region, eds. Synnøve Bendixsen and Trygve Wyller (London: Routledge), 113-28.

Mittermaier, Verena. 2009. 'Refuge in Europe? Church asylum as human rights work in fortress Europe. Refuge, 26(1): 68-70.

Oda, Hiroshi. 2013. 'Ethnography of relationships among church sanctuary actors in Germany', in Sanctuary Practices in International Perspectives, eds. Randy Lippert and Sean Rehaag (London: Routledge), 148-61.

Ökumenische Bundesarbeistsgemeinschaft Asyl in der Kirche. 2004. Asyl in der Kirche: Eine Dokumentation (Karlsruhe: Von Loeper Literaturverlag).

Patsias, Caroline, and Nastassia Williams. 2013. 'Religious sanctuary in France and Canada, in Sanctuary Practices in International Perspectives, eds. Randy Lippert and Sean Rehaag (London: Routledge), 175-88. 
Pessi, Anne Birgitta, and Henrietta Grönlund. 2012. 'The place of the church: public sector or civil society? Welfare provision of the Evangelical Lutheran Church of Finland, Journal of Church \& State, 54(3): 353-74.

Pohl, Christine. 2006. 'Responding to strangers: insights from the Christian tradition', Studies in Christian Ethics, 19(1): 81-101.

Price, Matthew. 2009. Rethinking Asylum: History, Purpose, Limits (Cambridge University Press).

Pyykkönen, Miikka. 2009. 'Deportation vs. sanctuary: the rationalities, technologies, and subjects of Finnish sanctuary practices', Refuge, 26(1): 20-32.

Rabben, Linda. 2016. Sanctuary and Asylum: A Social and Political History (Seattle: University of Washington Press).

Siirto, Ulla, and Hanna Niemi. 2019. 'Solidaarista yhdessä elämisen taitoa vai vieraanvaraisuutta: evankelisluterilaiset seurakunnat turvapaikkatyössä, in Turvapaikanhaku ja pakolaisuus Suomessa, eds. Eveliina Lyytinen (Turku: Siirtolaisuusinstituutti), 231-51.

Squire, Vicky. 2012. 'Attuning to mess', in Research Methods in Critical Security Studies, eds. Mark B. Salter and Can E. Mutlu (London: Routledge), 108-17.

Tomsho, Robert. 1987. The American Sanctuary Movement (Austin: Texas Monthly Press).

Yukich, Grace. 2013. 'I didn't know if this was sanctuary: strategic adaptation in the US New Sanctuary Movement', in Sanctuary Practices in International Perspectives, eds. Randy Lippert and Sean Rehaag (London: Routledge), 106-18. 